Bangladesh J. Bot. 40(1): 53-56, 2011 (June)

\title{
KARYOTYPE ANALYSIS WITH ORCEIN AND CMA IN TWO SPECIES OF ALOCASIA (SCHOTT) G. DON (ARACEAE)
}

\author{
Syeda Sharmeen Sultana, Hosne Ara ${ }^{1}$ and Sheikh Shamimul Alam* \\ Department of Botany, University of Dhaka, Dhaka-1000, Bangladesh
}

Key words: Alocasia, CMA, Karyotype analysis

\begin{abstract}
Alocasia fallax Schott and A. odora (Roxb.) Koch (Araceae) were investigated cytogenetically to confirm their taxonomic status. There is no report of $2 \mathrm{n}$ chromosome number for $A$. fallax in the available literature and internet information. Therefore the $2 n$ chromosome number $(2 n=28)$ found in this study is probably the first report for $A$. fallax. Alocasia odora showed exactly double $2 \mathrm{n}$ chromosome number $(2 \mathrm{n}=$ 56) from A. fallax. In addition to chromosome number, the other karyotypic features of $A$. odora were exactly double for that of $A$. fallax. The centromeric formulae of $A$. fallax was $24 \mathrm{~m}+4 \mathrm{sm}$ whereas it is just double in $A$. odora. Total length of $2 \mathrm{n}$ chromosome complement of $A$. odora $(62.58 \mu \mathrm{m})$ was almost double to $A$. fallax. The range of chromosomal length of the two species was almost same. Moreover, A. odora plant is much taller than A. fallax. All of these data suggests that $A$. odora might be an autotetraploid of $A$. fallax which in course of evolution had undergone some changes in GC-rich repeats.
\end{abstract}

\section{Introduction}

The genus Alocasia (Schott) G. Don (Araceae) is a medium-sized perennial herbs to rarely arborescent and gigantic. Alocasia has wide distribution in India (Darjeeling, Sikkim, Himalaya, Khasia Hills, Assam and Meghalaya of eastern India) and Bhutan. In Bangladesh, there are 11 Alocasia spp. (Siddiqui et al. 2007) widely found in the shady areas of hill slopes and foot hills in rain forest. Alocasia fallax and A. odora are two of them. Alocasia fallax has been reported from Netrokona and Mymensingh whereas A. odora from Bogra, Faridpur, Mymensingh and Sylhet districts in Bangladesh (Uddin et al. 2001). The rhizomes of Alocasia odora possess medicinal value in curing stomach ache, abdominal pain and cholera. The same is crushed into a paste and applied externally on the human body to cure abacessess and insect or snake bites (Heng 1979).

The Bangladesh National Herbarium (BNH) has been collecting different Alocasia species from all over the country and maintained in the garden of BNH. The different Alocasia species are mainly collected and identified on the basis of plant morphology. Therefore, a problem regarding authentic identification is existing since specimen may show different morphology in different environment due to phenotypic plasticity.

Generally karyotype analysis plays important role in determining the taxonomic status. When the different taxa showed same chromosome number and similar karyotypic features, then it is hard to distinguish between them by conventional cytological analysis. Fluorescent chromosome banding is one of the modern cytogenetic methods commonly used for critical karyotype analysis. Recently Deen and Alam 2002 and Alam and Deen 2002 were able to distinguish different forms of Colocasia esculenta and Xanthosoma violaceum by differential fluorescent banding.

The present work was undertaken to confirm the taxonomic status of A. fallax and A. odora by extensive karyotype analysis after staining with orcein and CMA.

\section{Materials and Methods}

Alocasia fallax and A. odora were collected from different districts of Bangladesh and maintained in the garden of Bangladesh National Herbarium (BNH).

*Corresponding author: <ssalam81@yahoo.com>. ${ }^{1}$ Bangladesh National Herbarium, Chiriakhana Road, Mirpur-1, Dhaka1216, Bangladesh. 
Alocasia fallax is a herb with short, suberect rhizome under $10 \mathrm{~cm}$ long. Leaves are moderately round shaped and slightly wrinkled inside. It shows 3 - 4 straight inflorescence. Alocasia odora is a large evergreen perennial herb, above-ground stem stout, 0.3 - $1.0 \mathrm{~m}$ high, 5 $15 \mathrm{~cm}$ thick, unbranched, base with stolons. Leaves are round in shape. It have 3 curved inflorescence.

Healthy and young root tips were collected and pretreated with $0.002 \mathrm{M}$ 8-hydroxyquinoline for $3 \mathrm{hrs}$ at room temperature $\left(28-30^{\circ} \mathrm{C}\right)$ followed by 15 min fixation in $45 \%$ acetic acid at $4^{\circ} \mathrm{C}$. These were then hydrolysed in a mixture of $1 \mathrm{~N} \mathrm{HCl}$ and $45 \%$ acetic acid $(2: 1)$ at $60^{\circ} \mathrm{C}$ for 30 sec. The shoot apices were stained and squashed in $2 \%$ aceto orcein. For fluorescent banding, Alam and Kondo's (1995) method was followed with slight modification. After hydrolysing and dissecting, the materials were squashed with $45 \%$ acetic acid. The cover glasses were removed quickly on dry ice and allowed to air dry for at least $48 \mathrm{hrs}$ before study. The air-dried slides were first pre-incubated in McIlvaine's buffer ( $\mathrm{pH}$ 7.0) for 30 min followed by Distamycin A (0.1 $\mathrm{mg} / \mathrm{ml}$ ) treatment for $10 \mathrm{~min}$. The slides were rinsed mildly in McIlvaine's buffer supplemented with $\mathrm{MgSO}_{4}(5 \mathrm{mM})$ for $15 \mathrm{~min}$. One drop of CMA $(0.1 \mathrm{mg} / \mathrm{ml})$ was added to the materials for 15 min and rinsed with Mcllvaine's buffer with $\mathrm{MgSO}_{4}$ for $10 \mathrm{~min}$. Slides were mounted in $50 \%$ glycerol and kept at $4^{\circ} \mathrm{C}$ for overnight before observation. These were observed under Hund fluorescent microscope with blue violet (BV) filter cassette.

\section{Results and Discussion}

Alocasia fallax and A. odora were found to possess $2 \mathrm{n}=28$ and $2 \mathrm{n}=56$ chromosomes, respectively (Figs 1, 3 ). Peterson (1989) reported $2 n=28$ chromosomes for A. odora. However, in this study this species showed $2 \mathrm{n}=56$ chromosomes which is a clear disagreement with that of Peterson (1989). On the other hand, there is no report of $2 \mathrm{n}$ chromosome number for A. fallax in the available literature and internet information (Encyclopedia of Flora and fauna of Bangladesh, Vol. 11, 2007). Therefore the $2 \mathrm{n}$ chromosome number $(2 \mathrm{n}=28)$ found in this study is probably the first report for A. fallax.

In addition to chromosome number, the other karyotypic features of A. odora were exactly double for that of A. fallax. Such as: (i) The centromeric formulae of A. fallax was $24 \mathrm{~m}+4 \mathrm{sm}$ whereas it is just double in A. odora (Figs 5, 6, Table 1). (ii) Total length of $2 \mathrm{n}$ chromosome complement of A. odora $(62.58 \mu \mathrm{m})$ was almost double to A. fallax (Table 1). (iii) The range of chromosomal length of the two spp. was almost same (Table 1).

Table 1. Comparative orcein and CMA-karyotype analysis in two species of Alocasia.

\begin{tabular}{lcccccc}
\hline Species & $2 \mathrm{n}$ & $\begin{array}{c}\text { Total length of } \\
\text { 2n chromosome } \\
\text { complement } \\
(\mu \mathrm{m})\end{array}$ & $\begin{array}{c}\text { Range of } \\
\text { chromosomal } \\
\text { length } \\
(\mu \mathrm{m})\end{array}$ & $\begin{array}{c}\text { Orcein } \\
\text { karyotype } \\
\text { formulae }\end{array}$ & $\begin{array}{c}\text { No. of } \\
\text { CMA } \\
\text { positive } \\
\text { bands }\end{array}$ & $\begin{array}{c}\text { \% of } \\
\text { GC-rich } \\
\text { repeats }\end{array}$ \\
\hline A. fallax & 28 & 29.30 & $0.42-1.35$ & $24 \mathrm{~m}+4 \mathrm{sm}$ & 15 & 21.50 \\
A. odora & 56 & 62.58 & $0.42-1.42$ & $48 \mathrm{~m}+8 \mathrm{sm}$ & 20 & 13.42 \\
\hline
\end{tabular}

$\mathrm{m}=$ metacentric chromosome, $\mathrm{sm}$ = sub-metacentric chromosome.

However, these two Alocasia spp. possessed different CMA-banding pattern. Fifteen comparatively large CMA-positve bands were found in A. fallax whereas smaller 20 CMA bands present in A. odora (Figs 2, 4). The percentage of GC-rich repeats in A. fallax and A. odora were 17.59 and $21.50 \%$, respectively. The CMA-banded regions of chromosomes are the GC-rich repeats (Schweizer 1976). It indicates that A. odora possessed little more GC-repeats. 
The $A$. odora has exactly double $2 \mathrm{n}$ chromosome number, total length of diploid complement and centromeric formulae to those of A. fallax (Figs 5-6). The range of chromosomal length is almost same in these two species. Although the GC-rich repeats are not double in A. odora, the
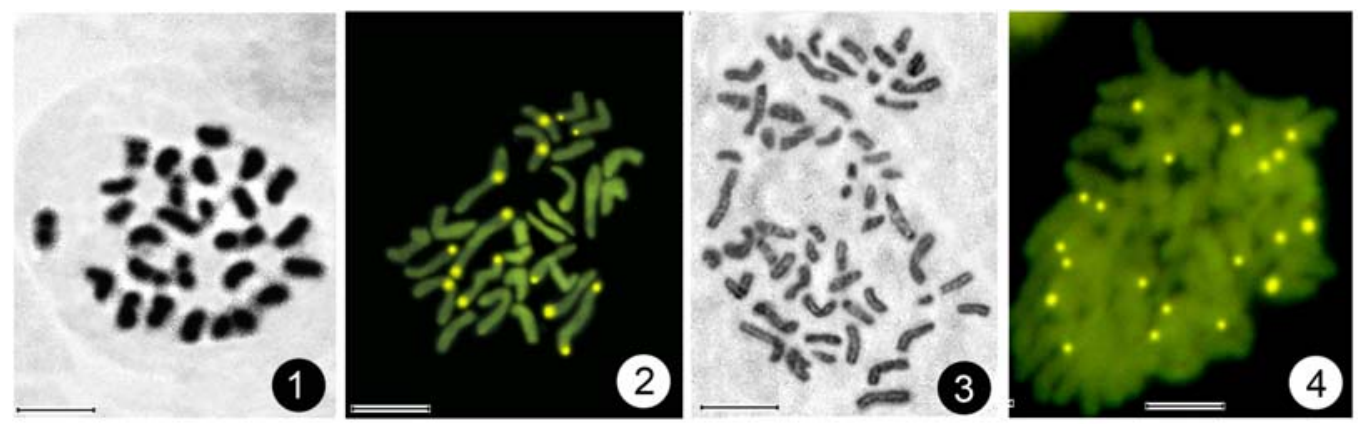

\section{$\begin{array}{llllllllllllll}\text { I } & \text { II } & \text { III } & \text { IV } & \text { V } & \text { VI } & \text { VII } & \text { VIII } & \text { IX } & \text { X } & \text { XI } & \text { XII } & \text { XIII } & \text { XIV }\end{array}$}

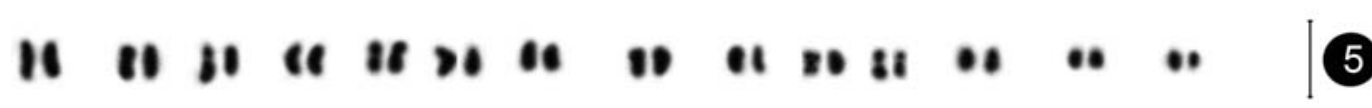

\section{$\begin{array}{lllllllllllllll}\text { I } & \text { II } & \text { III } & \text { IV } & \text { V } & \text { VI } & \text { VII } & \text { VIII } & \text { IX } & \text { X } & \text { XI } & \text { XII } & \text { XIII } & \text { XIV } & \text { XV }\end{array}$

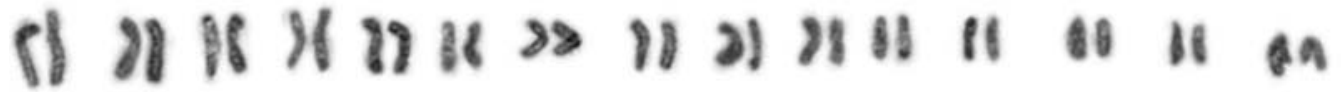

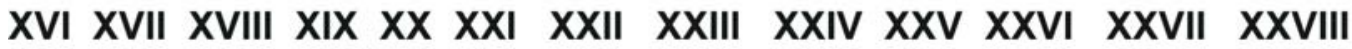

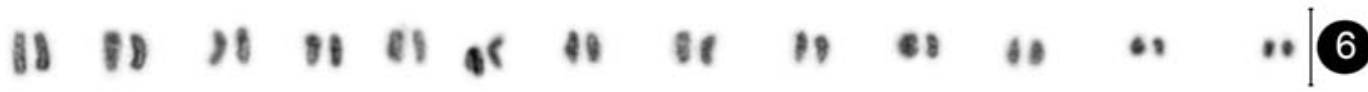

Figs 1-6. Mitotic metaphase chromosomes of two species of Alocasia. 1. Orcein-stained mitotic metaphase of Alocasia fallax. 2. CMA-stained mitotic metaphase of Alocasia fallax. 3. Orcein-stained mitotic metaphase of Alocasia odora. 4. CMA-stained mitotic pro-metaphase of Alocasia odora. 5. Karyotype prepared from orcein-stained mitotic metaphase of Alocasia fallax. 6. Karyotype prepared from orcein-stained mitotic metaphase of Alocasia odora. Bars $=10 \mu \mathrm{m}$.

percentage is more than A. fallax. Moreover, A. odora is much taller than A. fallax. All of these data suggests that $A$. odora might be an autotetraploid of $A$. fallax which in course of evolution had undergone some changes in GC-rich repeats.

\section{References}

Alam Sk S and K Kondo 1995. Differential staining with Orcein, Giemsa, CMA and DAPI for comparative chromosome study of 12 species of Australian Drosera (Droseraceae). Am. J. Bot. 82: 1278-1286.

Alam Sk S and SS Deen 2002. Karyotype and isozyme analysis in three forms of Colocasia esculenta (Araceae). Bangladesh J. Bot. 31(2): 95-98. 
Deen SS and Sk S Alam 2002. Comparative study in two forms of Xanthosoma violaceum (Araceae) through karyotype and isozyme analysis. Bangladesh J. Bot. 31(1): 45-47.

Siddiqui KU, MA Islam, ZU Ahmed, ZNT Begum, MA Hassan, M Khondker, MM Rahman, SMH Kabir, M Ahmad, ATM Ahmed, AKA Rahman and EU Haque (Eds) 2007. Encyclopedia of flora and fauna of Bangladesh. Vol. 11: 26-35. Angiosperms: Monocotyledons (Agavaceae-Najadaceae), Asiat. Soc. Bangladesh, Dhaka. 399 pp.

Heng Li 1979. Araceae. Fl. Reipubl. Popularis Sin. 13(2): 1-210.

Peterson G 1989. Cytology and Systematics of Araceae. Nord. J. Bot. 9: 119-166.

Schweizer D 1976. Reverse fluorescent chromosome banding with Chromomycin and DAPI. Chromosoma 58: 307-324.

Uddin MZ, H Ara and MA Hassan 2001. Alocasia fallax Schott (Araceae) - A new angiospermic record for Bangladesh. Bangladesh J. Plant Taxon. 8(2): 87-90.

(Manuscript received on 27 April, 2011; revised on 15 May, 2011) 